\title{
Özel Müzelerin Kent İmajına Etkisi Üzerine Nitel Bir Araştırma $^{1}$
}

\section{ÖZ}

Bu çalışma, özel müzelerin ortaya çıkış koşullarını değerlendirerek İstanbul'da bulunan özel müzelerin kent ile kurduğu ilişkiyi ele almaktadır. Küresel kent ağ1 içerisinde kentin markalaşma sürecinde özel müzelerin rolü anlaşılmaya çalışılmıştır. Bu amaçla hazırlanan çalışmada nitel araştırma yöntemi uygulanmıştır. Özel müzeleri ziyaret eden 16 kişi ile derinlemesine mülakat tekniği yapılmıştır. Kentin markalaşma süreci ve bu süreç içerisinde yaşadığı değişim ve dönüşümlerde kültürün aldığ1 rol ele alınarak özel müzelerin kentle bu bağlamda kurduğu ilişki giriş bölümünde incelenmiştir. Bulgular kısmında ise saha araştırmasından elde edilen veriler ele alınmıştır. Tartışma bölümünde ise araştırma sonucu ile elde edilen bulgular değerlendirilmiştir. Özel müzelerin, kentte yer seçiminde bulunurken kentin simge mekânlarını tercih ettiğini bu anlamda hem kendini hem de kenti markalaştırdığı ifade edilmiştir.

\section{Anahtar Kelimeler}

Özel Müze, Müze, Kent, Kent İmajı, İstanbul 


\title{
A Qualitative Research on the Effect of Private Museums on the Image of the City
}

\begin{abstract}
This study examines the relationship between the private museums in Istanbul and the city by evaluating the conditions of the occurrence of private museums. The role of private museums in the branding process of the city within the global city network has been tried to be understood. Qualitative research method was used in the study prepared for this purpose. An in-depth interview technique was conducted with 16 people who visited private museums. The branding process of the city and the role of culture in the changes and transformations which is experienced in this process are discussed and the relationship established by private museums with the city in this context is examined in the introduction section. In the findings section, the data obtained from the field research were discussed. In the discussion part, the findings obtained with the result of the research were evaluated. It is stated that private museums prefer the city's symbolic places while choosing a place in the city, and in this sense, they brand both themselves and the city.
\end{abstract}

Keywords

Private Museum, Museum, Kent, Image of the City, Istanbul 
İlham perilerinin mabedi anlaminı taşıyan müzeler, klasik anlayışta eserlerin toplandığı ve sergilendiği mekânlar olarak ele alınmaktadır. Yeni müzecilik anlayışında ise yalnızca eserlerin bir araya getirilerek korunduğu mekânlar olmanın ötesinde ziyaretçilerinin aktif katılım sağladığı, müzede düzenlenen etkinlikler ve atölyeler sayesinde sürekli olarak aktif olan ve canlı kalabilen mekânlara dönüşmüştür. Yeni müzecilik anlayışının simgesi olarak karşımıza çıkan özel müzeler ise Türkiye'de ilk kez 1980 yılında açılmıştır. İlk özel müze olan Sadberk Hanım Müzesi'nin bu tarihte açılmasında dönemin ekonomi politikaları etkili olmuştur. 24 Ocak Kararları olarak anılan ve uygulamaya konulan ekonomik program neticesinde 1980 yılı itibariyle özelleştirme dönemi yaşanmıştır. Özal Dönemi olarak adlandırılan dönemde girişimcilik önemsenmiş ve desteklenmiştir. Ekonomik alandaki yaklaşımlar kültürel alana da yansımıștır. Bu özelleştirme sürecinin etkileri yoğun olarak kültürü de özelleştirmiştir. Bu sebeple 1980 sonrasında ülkemizdeki özel müze sayısı zaman içerisinde artmıştır.

İlk özel müze olan Sadberk Hanım Müzesi'nin kurulmasindan sonra zaman içinde özel müze sayısı ülkemizde artmıştır. 2000'li yıllarda ise ülkemizde müze sayısında önemli bir artış yaşanmıştır. Modern ve çağdaş sanatı düzenli ve kalıcı olarak sergileyen ilk müze olan İstanbul Modern'in 2004 yılında açılması sonrasında ise Pera Müzesi, Sabancı Müzesi ve 2007 yılında Santral İstanbul'un açılması bu artışın işaretleridir. 2000 yılı başlarında yalnızca sanatçı, koleksiyoner ve galericilerin uğrak noktası olan bu mekânlar artık popüler kültürü ilgi- lendiren bir yatırım aracı halini almıştır (Çalıkoğlu, 2009, s. 15). 2000 yılına kadar İstanbul'da bulunan özel müze sayısı 20 iken Kültür ve Turizm Bakanlığı verilerine göre 2020 yılına gelindiğinde bu sayı 63'e ulaşmıştır. Kültür ve Turizm Bakanlığ 1 verilerine göre ülkemizde 286 özel müze bulunmaktadır. Özel müzelerin 63'ü İstanbul'da yer alarak birinci sıradadır.

Kentte sayısı gittikçe artan özel müzelerin kent ile olan ilişkisi, kente olan yansımaları ve etkileri bulunmaktadır. $\mathrm{Bu}$ etkiler kentlerin ulusal ve uluslararası düzlemde kendilerini ifade etme, diğer kentlerden farklılaşarak önde olma girişimlerinde öne çıkmaktadır. Bu anlamda kültürel etkinlikler önemlidir. Söz konusu etkinlikler ve kente olan etkisi, İstanbul özelinde 2010 Avrupa Kültür Başkenti uygulaması ve bienal etkinliği ile gözle görülür hale gelmiştir.

İlk özel müzenin İstanbul'da kurulması ve zaman içerisinde kentte artış göstermesinde şahıs ve kurum koleksiyonların önem arz etmesiyle beraber uluslararası etkilerinin de rolü büyüktür. İstanbul'da gerçekleştirilen bienal etkinlikleri ve 2010 İstanbul Avrupa Kültür Başkenti çalışmaları, müzecilik çalışmaları adına önemli bir eşiktir. Kentin dünya kamuoyunda görünür hale gelerek ziyaretçi sayısını ve tanınırlığını artırması adına bu çalışmalar etkin rol oynamıştır.

1980 sonrasında yaşanan küreselleşme etkileri ile İstanbul bir dönüşüm sürecine girmiştir. Kentte yaşanan göçlerle nüfus artmıştır. Bu durum kentin yeni ihtiyaçlarını doğurmuş ve bu çerçevede yatırımlar gerçekleştirilmiştir. Kentte gelişen yatırımlar ve büyük kentsel projeler ile birlikte büyük alışveriş merkezleri ve oteller kendisini göstermiştir. Küreselleşme ile kentte düzenlenen et- 
kinliklere bienal örneğini veren İlhan, Tarihi Yarımada da gerçekleşen etkinlikler için tarihe de atıf yapıldığını böylelikle çağdaş sanat ile tarihsel geçmişin birleştiğini, bu zenginliğin küresel yarışta diğer kentlere nazaran ayırıcı olduğunu belirtmiştir. Böylelikle kentin tanınırlığ ve küresel kültür sermayesinde kentin hissesine düşen oranda da artış olacaktır (İlhan Z., 2019, s. 49). Kentin kendine has özellikleri olan tarihi yapısı, kültürel özellikleri gibi unsurlar kentin tanıtımında değerlendirilmiştir.

Uluslararası İstanbul Bienali gelişim sürecine bakıldığında özel sektörün çaıışmaları dikkat çekmektedir. 1973 yılında Nejat Eczacıbaşı tarafindan kurulan İstanbul Kültür Sanat Vakfi, ilk festivalini bu tarihte düzenlemiştir. 1980 yılına kadar İstanbul Festivali'nde opera, bale, tiyatro ve konser, geleneksel gölge oyunları gibi çeşitli etkinlikler düzenlenmiş, 1982 sonrasinda Film Haftasi programa eklenmiş, 1989 yılında ise İstanbul Uluslararası Film Festivali’ne dönüşmüştür. 1994 yılında bu etkinlik İstanbul Uluslararası Caz Festivali ve İstanbul Uluslararası Müzik Festivali olarak iki kısma ayrılmıştır. 1987 yılında ise ilk olarak Uluslararası İstanbul Bienali düzenlenmiştir (Yardımc1, 2014, s. 15). İstanbul bienali gerçekleşmeden önce de kentte aktif bir biçimde kültürel faaliyetler düzenlenmekteydi.

Bienal etkinliği, neoliberal küresel politikalar bağlamında kentin pazarlanması ve tanıtımına aracı olan bir etkinlik olduğunu ve bu söylemin tartışılan konulardan biri olduğunu ifade eden Özpınar, söz edilen yaklaşımın bienalin düzenlendiği kent adına iyi bir imge oluşturmanın ötesinde, kentin görülüp yatırım yapmaya değecek kadar liberal, kültürel ve demokratik bir alan olarak kurgulanmaya çalışıldığını belirtmiştir. (Özpınar, 2011). Kentin tanınırlığının artması, kente gelen yerli ve yabancı turist sayısında artış yaşanması ve kentin markalaşması aynı zamanda kenti çeşitli yatırımcılar içinde bir cazibe merkezi haline getirmektedir.

İstanbul Avrupa Kültür Başkenti projesine başvuru yapmadaki motivasyon ise İstanbul'un bu unvanı hak etmesine inanmaktan gelmekte olup birçok kamu kuruluşu ve sivil toplum kuruluşlarından da destek görmüştür (Yardımc1, 2014, s. 73). Küresel arenada görünür ve söz sahibi olmak adına yapılan çalışmalar kapsamında kültür başkentliği uygulaması da dikkate alınabilir. Söz konusu etkinlikler ile kentin markalaştırma sürecine bir destekte sağlanmasının amaçlandığı ifade edilebilir.

İstanbul'un, Avrupa Kültür Başkenti olma yolundaki süreci 1999 yılında Avrupa Birliği adayı olan ülkelerin kentlerine Avrupa Kültür Başkenti unvanı verilme kararının alınması ile başlamıştır. Avrupa Kültür Başkenti unvanının alınması adına gerekli çalışmaların yapılması için Girişim Grubu kurulmuştur. Böylelikle yerel ve merkezi yönetimin desteğini alarak üniversiteler ve diğer sivil toplum örgütleri ile görüşmelerde bulunulmuştur. Süreç, 13 Kasım 2006 günü Avrupa Parlamentosu'nun görüşü ve Avrupa Birliği Kültür Bakanları Konseyi'nin vermiş olduğu onay neticesinde İstanbul'un, 2010 Avrupa Kültür Başkenti olduğu ilan edilmiştir (Mimarizm, 2009).

2010 yllında ise İstanbul, Avrupa Kültür Başkenti seçilmiştir. Seçimin öncesinde yaşanan değişimlere bakıldığında; 1980'li yıllar kentte yaşanan kentsel dönüşüm ile İstanbul'u bir dünya kenti 
haline getirme düşüncesinde ilk binaen hareketinin desteğinin olduğu yıllardır. Kentte oluşan yoğun göçler sonucunda değişim ve dönüşümler yaşanmıştır. Kültürel etkinlikler de bu dönemde hızlanmıştır. 1973 yılında kentte festivaller, 1987'de ise bienaller gerçekleştirilmeye başlanmıştır. Müzecilik, koleksiyonerlik gibi alanlarda 2000'li ylllarda ciddi manada gelişmeler yaşanmıştır. Kültürel ve sanatsal anlamda yaşanan bu hareketlilikle beraber İstanbul, 2010 yılında “Avrupa Kültür Başkenti” seçilmiştir (Cançat, 2016, s. 229). Söz edilen hareketliliğin yaşanmasında Türkiye'deki Koç, Sabanc1, Eczacıbaşı gibi ailelerin çalışmaları etkilidir (Şeni, 2011). Adı anılan aileler özel müzelerin açılması, koleksiyonerlik ve galericilik faaliyetlerinin artmasında da etkili olmuştur.

Avrupa Kültür Başkenti kapsamında kentte çeşitli yenileme faaliyetleri gerçekleştirilmiştir. Kentsel bir okuma ile Avrupa Kültür Başkenti programı incelendiğinde, kentsel anlamda mevcut tarihî zenginlikleri değerlendirmeye yönelik projelerin çoğunlukta olduğunu ifade eden Yavuz; restorasyon, onarım ve bakım projeleri ve mevcut tarihî eserlerin yeniden işlev kazandırılan yenileme çalışmaları sıklıkla rastlanan projeler olduğunu ifade etmiştir. Buna ek olarak, yeni kültürel mekân oluşumları ve aydınlatma çalışmaları yapılmıştır (Yavuz, 2009).

Avrupa Kültür Başkenti unvanının kent için firsat olarak görüldüğünü ifade eden Hein, şehirlerin AKB sürecinde yapılan çalışma ve etkinlikleri kentsel dönüşümün bir aracısı olarak görüldüğünden söz eder (Hein, 2010). İstanbul'da program kapsamında restorasyon projelerine ağırlık verilmiş, yeni kültürel yapı inşasına diğer son dönem baş- kentleri kadar önem verilmemiştir. 2001 yılı sonrasında çoğu kentte tercih edilmiş olan ikonik modern yapı tasarımı İstanbul için ele alınmamıştır. Hazırlanan projeler diğer Avrupa Kültür Başkenti kentlerinde olduğu gibi kültürel içerikli olmuştur. Program, kültürel mirasın yenilenmesine dayanır. Oluşturulan yeni kültürel yapılar ağırlıklı olarak var olan yapıların yenilenerek kültür amaçlı işlevlendirilmesi sayesinde elde edilmiştir (Öktem \& Görgülü, 2011). Söz konusu çalışmalar ile kentin öne çıkan özellikleri vurgulanarak kentin çekim merkezi halini almasına çalışıldığı ifade edilebilir.

İstanbul 2010 Avrupa Kültür Başkenti Ajansı, Kentsel Uygulamalar Direktörü Korhan Gümüş̧ün vermiş olduğu röportajda, "Kentler yüzyılı" denen bu yüzyılda, kent yönetimlerinin politik işlevi değişiyor ve kültür çok önemli bir stratejik araç haline geliyor; sanat kentlerin kendi gelecekleri üzerinde düşünmelerini sağlayan bir düşünce geliştirme alanı oluyor" ifadesinde bulunmuştur (Mimarizm, 2009). Kentlerin küresel ölçekte görünür olma isteği ve bu yöndeki çabasında kültürel etkinlikler önemli yer tutar. Bu anlamda sadece etkinlikler değil kültürel çalışmaları desteklemek amaçlı inşa edilen yapılarda önemli olup müzeler bu çerçevede değerlendirilebilir. Müzelerin tasarımı, mimari yapıları bulunduğu kente anlam katar ve esasında o kenti diğerlerinden farklılaştırır.

Müze bina tasarımlarının kent için turistik anlamda etkisi dikkate değerdir. Levent Çalıkoğlu'nun Ali Artun ile yaptığ 1 görüşmede Artun, müze binalarının yapımında mimarinin öne çıktığını belirterek bir gösteri mimarlığının amaçlandığını söylüyor. İşlevin önemli olmadığını uçuk yapıdaki müze bina- 
sının adeta bir katedral gibi büyüleyici ve ikonik olup kenti mühürleme isteğinden söz ediyor. Kenti yönetenlerin bu 'mühürleme' isteğini Katar Şeyhi'nin İslam Eserleri Müzesi için mimar Pei'ye 'uç uçabildiğin kadar' yetkisini verdiğini ifade ederek örneklendiriyor (Çalıkoğlu, 2009, s. 27). Müzeler, kent için görünür olan ve bu görünürlük sayesinde kentin ışıltısını uluslararası ölçekte ziyaretçilere bir anlamda da müşterilere ulaştıran mekânlardır. Bu çerçevede değerlendirildiğinde kültürün, kentin şekillendirilmesinde ve uluslararası arenada görünebilir bir hal almasında kent yöneticileri için önemli bir araç olduğu söylenebilir.

Kentte özel müzelerin gün geçtikçe çoğalması, şahıs ve kurum koleksiyonlarının müzeye dönüştürülmesi, festivallerin çeşitlenerek düzenlenmesi, bienal gibi uluslararası etkinliklere ev sahipliği yapılması ve 1980 sonrası uygulanan ekonomik politikalar ve kentsel dönüşüm faaliyetleri gibi uygulanan çalışmalar neticesinde, küresel kamuoyuna kentin kültür aracılığı ile gösterişli bir biçimde sunulduğunu söylemek yanlış olmayabilir. Farklı yönetimlere başkentlik yapmış olan İstanbul'un geçmişteki ihtişamına vurgu yapılarak Batı'ya dönük yüzü kültürel araçlar ile kent sahnesinde sergilenmiş bir şekilde adeta izleyicisini beklemektedir. Kentin dünya sahnesine konu olmasında müzeler için seçilen mekânlar önem kazanır. Sanat galerileri ve özel müzeler genellikle Beyoğlu sınırları içerisinde yer almaktadır. $\mathrm{Bu}$ anlamda Beyoğlu kültür-sanat faaliyetlerinin yürütüldüğü önemli bir yerdir.

Kültürel değerlerin ekonomik bir değer olarak değerlendirilmesini, Yerden (2017, s. 22) ortak tarihe dair şuurun korunmasının dışında ekonomik bir kaynağın korunması olarak ele almıştır. $\mathrm{Bu}$ anlamdaki koruma yaklaşımları da yalnızca mekân koruması değil, aynı zamanda işlevselleşmesi ve o mekânın ekonomik değer olarak ortaya çıkarılması olduğuna da işaret eder.

İstanbul'un tarihsel geçmişi olan Beyoğlu, Haliç gibi ilçelerinde kültürün arac1lığ ile dönüşüm geçirmesi ve buranın müzelere, sanat sergileri ve etkinliklerine ev sahipliği yapması söz konusudur.

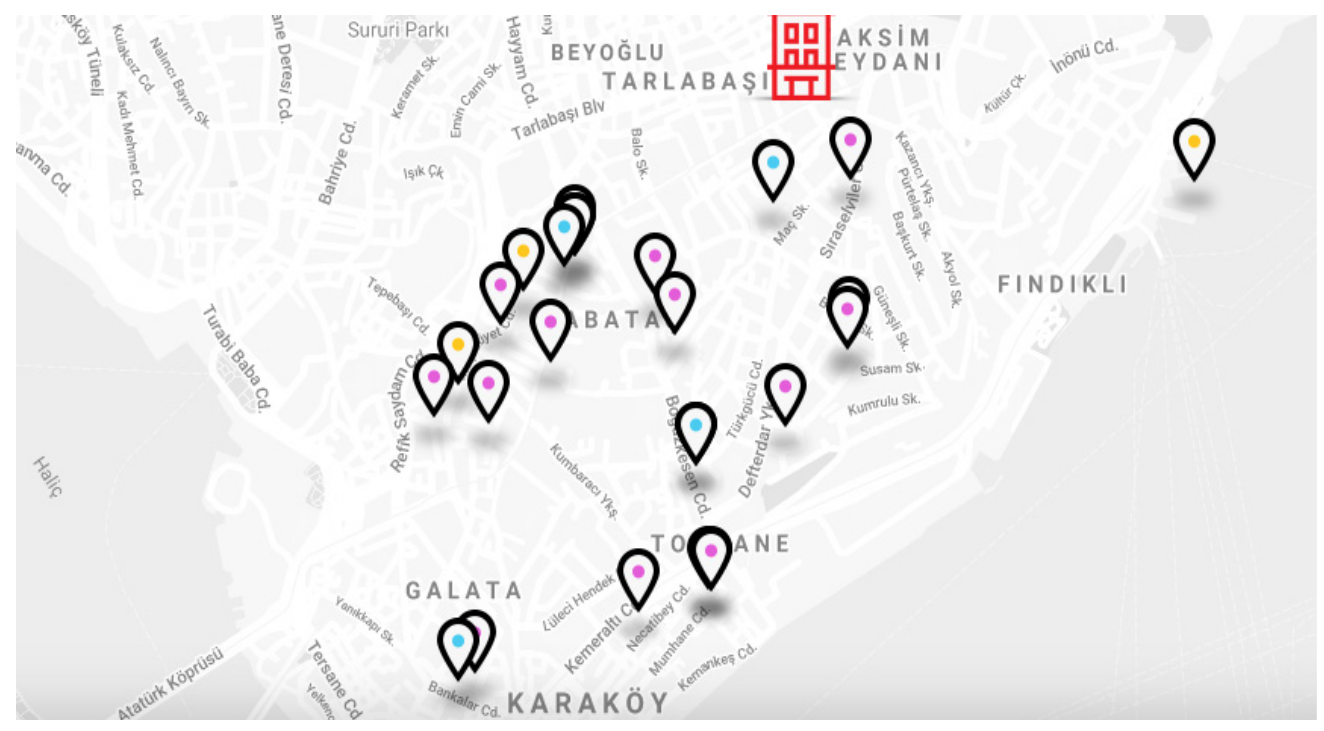


Görsel 1: Sanat galerileri, kurumları ve müzelerin dağılımı, Kaynak: https://www.akbanksanat.com/ sanat-haritasi Erişim Tarihi: 23.06.2020

(Sar1 noktalar: müzeler; Turuncu noktalar: sanat galerileri; Mavi noktalar: sanat kurumlarıdır.)

Özel müzelerin yer seçimi için dikkat ettikleri hususlara bakıldığında Rahmi M. Koç'un ifadelerini incelemekte fayda bulunmaktadır. Haliç kıyısında konumlanan Rahmi Koç Müzesi'nin yer seçimi hakkında Rahmi Koç şu sözleri dile getirmiştir: "Lengerhane hazır olunca, İstanbul'un görece geri kalmış bir bölgesini canlandırmak ve desteklemek için sunduğu harika firsatın tam anlamıla bilincindeydik... Haliç'in ve komşu kıyı bölgelerinin geleceği konusunda, bu bölgelerin saygıdeğer gelişimciler, aydın planlamacı ve mimarlar tarafindan ele alınmasını can-1 gönülden umut ediyorum, çünkü bu bölgeler, İstanbul'un en güzel ve dinamik semtleri arasında yer alabilecek potansiyeli taşıyor" (Akaş, 2006, s. 11). Kentin belirli bir bölümünün canlandırılması, turistik bir alan haline getirilmesi ve böylelikle kentin markalaştırılması adına özel müzelerin rolü bu ifadelerde de gözler önüne serilmektedir.

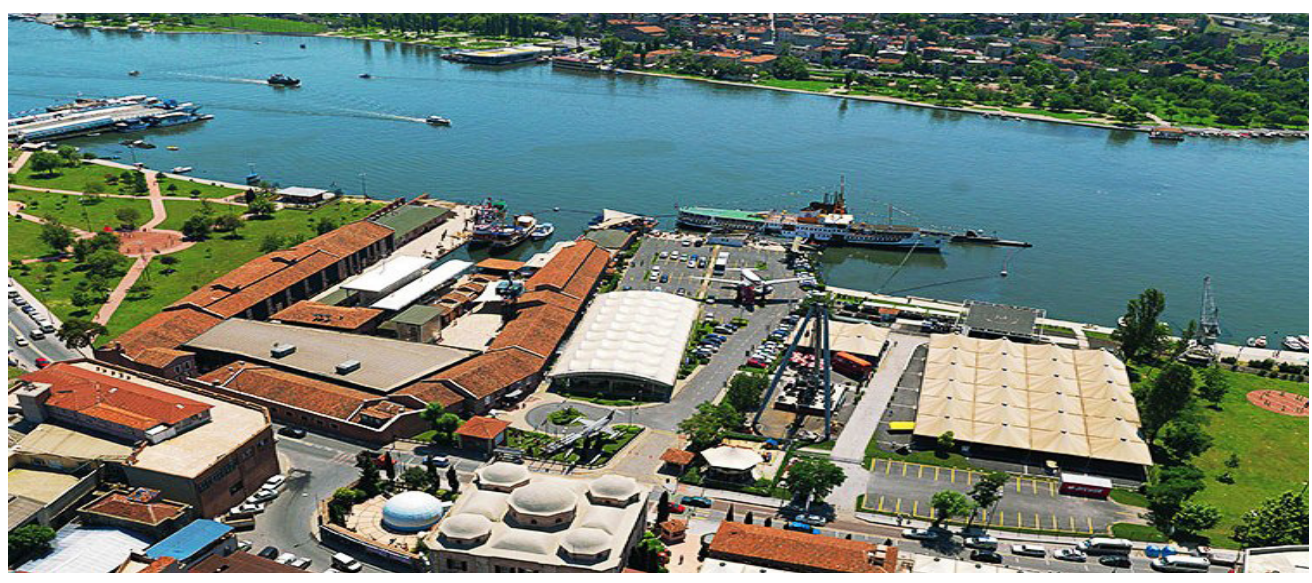

Görsel 2: Rahmi M. Koç Müzesi yerleşkesi, Kaynak: https:||istanbeautiful.com/tr/istanbul-rahmi-koc-muzesi/ , Erişim tarihi: 29.11.2020

İstanbul Haliç örneğine benzer nitelikte olan bir başka örnek ise Guggenheim Bilbao Müzesi'dir. Endüstri kenti olan Bilbao, Guggenheim Müzesi inşasından sonra sanayi ve madencilik merkezi özelliğinden ziyade İspanya'nın turizm merkezi olarak anılmaya başlanmıștır. Müzenin tasarımı sanayi ve tasarımın birleşmesinin eseri olarak görülmektedir. Kentin sanayiye dayanan özelliği ve sonrasında müzenin yapılması ile değişen karakteri nedeni ile Tonguç, Guggenheim Bilbao Müzesi için "bir şehrin kaderini değiştiren ilginç müze” olarak söz etmektedir (Tonguç, 2017). 


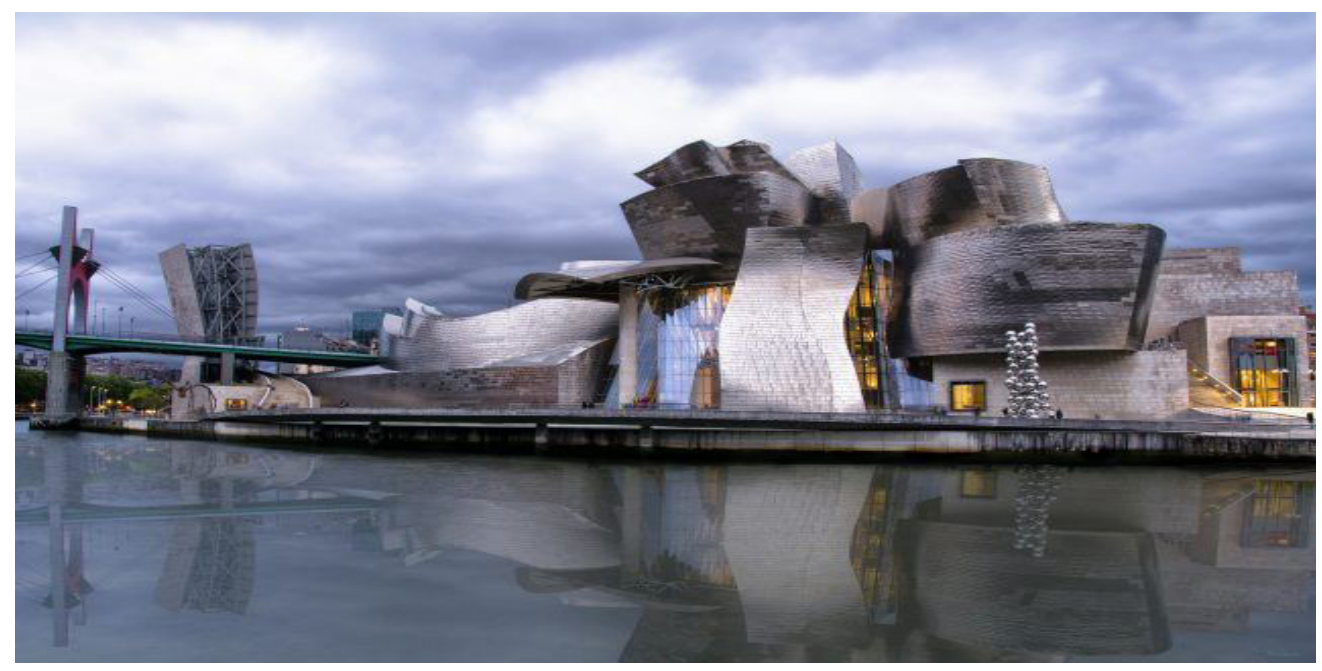

Görsel 3: Guggenheim Bilbao Müzesi, Kaynak: https://www.arkitektuel.com/guggenheim-bilbao-muzesi/ Erişim tarihi: 29.11.2020

Frank Gehry'nin tasarladı̆̆ı Guggenheim Müzesi Bilbao, müzenin açıldığ1 1997 yılından günümüze kadar on milyondan fazla ziyaretçi ağırlamıștır. Gemi yapımı ile ilgilenen endüstri ve sanayi kenti olan Bilbao, müzenin açılışı itibari ile kültürel ve mimari bir merkez haline gelmiştir.

Kentin eski sanayi bölgesinde yer alan müze, Bilbao'nun kentsel dönüşüm projesi için öncü bir adımdır. Müze ile kent cazibe merkezi haline gelmiş ve turist sayısını artırmıştır. "Guggenheim etkisi" kavramı müzenin açılışı sonrasında şehre olan ziyaretçi akını neticesinde ortaya çıkmıştır (World Tourism Group). Zira Guggenheim Bilbao Müzesi'nin açılmasıyla birlikte sanayi kenti zamanla turistik bir kimliğe bürünmüş ve çok sayıda turist ağırlamıştır (Aktuğlu \& Balık, 2009).

Kültürün kentin ekonomik olarak canlandırılmasında oynadığı rol söz edilen örneklerde açıklanmaya çalışılmıştır. Kültürün kentlerin çekim merkezi haline gelmesindeki aracı rolü
2018 y1lında gerçekleştirilen İstanbul Kültür Çalıştayı'nda ele alınmıştır. Burada kentin kültürel araçlarla bir çekim merkezi haline gelmesi hususunda değerlendirilmelerde bulunulmuştur. İstanbul'da oluşan modern sanatların uyum içerisinde bir arada olması adına fikirler değerlendirilmiştir (2018, s. 23). Kentin uluslararası düzlemde tanıtımı ve tanınırlığı açısından kültürün aracı konumu giderek önem kazanmaktadır. $\mathrm{Bu}$ açıdan değerlendirildiğinde kültürel mekân olarak müzeler, kentin imajına bir katkı sunmaktadır.

Kültürel unsurlar, küreselleşme etkisi ile dünyanın her bir noktasındaki insana ulaşmakta ve bu kişilere merak uyandırmaktadır. Böylelikle insanlar, farklı kültürleri merak etmekte ve bu merak neticesinde onların peşine düşmektedir.

Kültürel değerlerin ilgi çekici özelliğine vurgu yapan Zeren, kentlerin bu değerler ile önemli bir 'cazibe merkezleri’ haline gelmesine işaret etmiştir. Bu 
çerçevede kültür, kentin markalaşmas1 noktasında önemli bir unsur olarak karşılık bulmaktadır (Zeren, 2012, s. 99). Kentlerin markalaşma yöndeki çabalarının küreselleşme ile arttığı söylenebilir. Zira kentler kendilerini diğerlerinden farklılaştırarak ön planda tutmak istemektedir. Bu anlamda Koçyiğit ve Aktan, kentlerin adeta rekabete girdiğinden söz ederek yarışı kazanmak için kentlerin farklı stratejiler geliştirmesi gerekliliğini vurgulamıştır (Koçyiğit \& Aktan, 2020, s. 4). Söz edilen rekabet ortamı, küresel düzlemde olup burada kişiler, mekânlar ve kentler de markalaşma çabasına girerek ürün ve hizmetler gibi değerlendirilmektedir (Yalım, 2017, s. 2). "Marka kent olmak; dişarıdan kendine yönelimi artırabilmek demektir. Kente doğru nitelikli bir akışın yaratılması ve bunun sürdürülebilirliğinin sağlanması güçlü bir kent markası olduğunuz anlamına gelir" (Henden Şolt, 2018, s. 132). Kentlerin kendilerini diğer kentlerden ayırt etme, dünya kamuoyunda görünür olma amacı ile markalaşma yoluna girmekte ve bu noktada kültür ürünlerinden beslenmektedir.

Küresel ölçekteki rekabet ortamında bir kentin ön plana çıkmasını ve markalaşmasını sağlayan unsurlar yalnızca kentin sahip olduğu yer altı ve yer üstü zenginlikler değil onlara ek olarak sosyal anlamda ön plana çıkmasını sağlayacak öğelerdir (Koçyiğit \& Aktan, 2020, s. 2). Marka kent olma yolunda o kentin tarihsel geçmişi, coğrafi imkânları, kültürel ve ekonomik özellikleri marka oluşturma altyapısı olarak öne çıkmaktadır. Yalım bu çerçevede İstanbul'un tarihsel geçmişine vurgu yaparak kent tanıtımında ya da marka oluşumunda bu niteliğin önemini belirtmiştir (Yalım, 2017, s. 6).
İstanbul'un farklı medeniyetlere ev sahipliği yapması, her bir kössesinde tarihe atıf yapan değerlerinin bulunması böylelikle kentin açık hava müzesi niteliği taşıması gibi özellikler kentin tanıtımında kullanılarak marka kent olma yönündeki çalışmalarda değerlendirilmektedir.

\section{Yöntem}

$\mathrm{Bu}$ çalışmada nitel araştırma yöntemi kullanılmıştır. Özel müzelerin kent ile olan ilişkisini anlamak adına nitel araştırma yönteminin faydalı olacağı düşünüllmüştür. Araştırma sahasını İstanbul Modern Müzesi, Pera Müzesi, Sakıp Sabancı Müzesi, Oyuncak Müzesi ve Rahmi Koç Müzesi oluşturmaktadır. İstanbul'da bulunan 63 özel müze içerisinden bu 5 özel müzenin seçimi yapılırken birtakım hususlara dikkat edilmiştir. Öncelikle özel müzelerin koleksiyonları incelenmiştir. Sonrasında ise müzelerin web siteleri, sosyal medya hesapları incelenmiştir. Süreli, güncel sergiler düzenleyen, sosyal medya hesaplarını aktif olarak kullanan özel müzeler değerlendirilmiş ve bu beş özel müze seçilmiştir.

Araştırmada, İstanbul'daki özel müzelerin kentteki rolünü ve müze ziyaretçilerinin deneyimlerini anlamak adına fenomenolojik yaklaşım benimsenmiştir. Kaynağını psikoloji ve felsefeden alan fenomenolojik araştırmada, bir fenomenle ilgili bireylerin yaşanılan deneyimleri betimlenerek ele alınan araştırma desenidir (Creswell, 2017, s. 14). Bireylerin araştırma fenomeni ile ilgili çeşitli deneyimlerin özüne ulaşabilmek için Creswell fenomenolojik araştırmaya işaret etmiştir.

\section{Örneklem}

Araştırma sahasını oluşturan İstanbul Modern Müzesi, Pera Müzesi, Sakıp 
Sabancı Müzesi, Oyuncak Müzesi ve Rahmi Koç Müzesi ziyaretçileri ile müzelerin kafelerinde görüşme yapılması planlanmıştır. Saha gözlemleri sırasında müze yetkilileri ile görüşülerek görüşme yapılması için izin talep edilmiştir. Fakat bir müze dışında diğer dört müze bu noktada izin vermemiştir. Bu durum araştırmacının müze ziyaretinde bulunan 3 arkadaşı ile mülakat yapması ve kendilerinin diğer 13 katılımcıya ulaştırması neticesinde çözülmüştür. 16 kişi ile derinlemesine görüşme yapılmıştır.

\section{Çalışma Grubu}

Çalışma grubu 9 kadın ve 7 erkek olmak üzere 16 kişiden oluşmaktadır.
Katılımcıların demografik özelliklerine bakıldığında, yaş aralığı 23-42 arasındadir. Katılımciların 2'si doktora mezunu olup 1 katılımcı doktora öğrencisidir. 3 katılımcı yüksek lisans öğrencisidir. 9 katılımcı lisans mezunu olup 1 katılımc1 lisans son sınıf öğrencisidir. Katılımcıların tamamı ekonomik durumlarını orta olarak belirtmiştir.

Çalışma grubunu oluşturan görüşmeciler hakkında bilgiler aşağıdaki tabloda kodlar ile ifade edilmiştir. Görüşmecilerin kodlaması "tablodaki numarası, cinsiyeti, yaşı" sıralaması ile oluşturulmuştur. İkamet yeri bilgisi katılımcıların ifade ettiği şekilde verilmiştir.

\begin{tabular}{|c|c|c|c|c|c|c|c|}
\hline No & Kod & $\begin{array}{l}\text { Meslek (İş } \\
\text { Durumu) }\end{array}$ & $\begin{array}{l}\text { Eğitim } \\
\text { Durumu }\end{array}$ & İkamet Yeri & $\begin{array}{l}\text { Ekonomik } \\
\text { Durum }\end{array}$ & $\begin{array}{l}\text { Medeni } \\
\text { Durum }\end{array}$ & \\
\hline 1 & $\mathrm{~K} 1, \mathrm{E}, 38$ & $\begin{array}{l}\text { Bilgisayar } \\
\text { mühendisi }\end{array}$ & Lisans & Kozyatağ1 & Orta & Bekâr & $\mathrm{X}$ \\
\hline 2 & $\mathrm{~K} 2, \mathrm{E}, 23$ & $\begin{array}{l}\text { Öğrenci (Üni } \\
\text { son sinıf) }\end{array}$ & Lisans & Kartal & Orta & Bekâr & $\mathrm{X}$ \\
\hline 3 & K3,E,24 & $\begin{array}{l}\text { Reklamcı } \\
\text { (metin } \\
\text { yazarı) }\end{array}$ & Lisans & Pendik & Orta & Bekâr & $\mathrm{X}$ \\
\hline 4 & $\mathrm{~K} 4, \mathrm{~K}, 37$ & $\begin{array}{l}\text { Denetim } \\
\text { müdürü }\end{array}$ & Doktora & Maslak & Orta & Evli & 2 \\
\hline 5 & $\mathrm{~K} 5, \mathrm{E}, 30$ & $\begin{array}{l}\text { Kurumsal } \\
\text { iletişimci }\end{array}$ & Lisans & İstinye & Orta & Bekâr & $\mathrm{X}$ \\
\hline 6 & K6,K,28 & Öğrenci & $\begin{array}{l}\text { YL } \\
\text { öğrencisi }\end{array}$ & Çekmeköy & Orta & Bekâr & $\mathrm{X}$ \\
\hline 7 & $\mathrm{~K} 7, \mathrm{~K}, 30$ & Öğretmen & $\begin{array}{l}\text { Doktora } \\
\text { öğrencisi }\end{array}$ & Bulgurlu & Orta & Bekâr & $\mathrm{X}$ \\
\hline 8 & $\mathrm{~K} 8, \mathrm{~K}, 28$ & Muhasebeci & Lisans & Maslak & Orta & Evli & $\mathrm{X}$ \\
\hline 9 & K9,K,30 & $\begin{array}{l}\text { İnsan } \\
\text { kaynakları } \\
\text { uzmanı }\end{array}$ & Lisans & Erenköy & Orta & Evli & 1 \\
\hline 10 & $\mathrm{~K} 10, \mathrm{E}, 28$ & Gezi rehberi & YL & Üsküdar & Orta & Evli & $\mathrm{X}$ \\
\hline
\end{tabular}




\begin{tabular}{|l|l|l|l|l|l|l|l|}
\hline 11 & K11,K,30 & $\begin{array}{l}\text { Denetim } \\
\text { uzmanı }\end{array}$ & Lisans & Ümraniye & Orta & Bekâr & X \\
\hline 12 & K12,E,24 & Öğrenci & $\begin{array}{l}\text { YL } \\
\text { öğrencisi }\end{array}$ & Pendik & Orta & Bekâr & X \\
\hline 13 & K13,K,24 & Öğrenci & $\begin{array}{l}\text { YL } \\
\text { ŏğrencisi }\end{array}$ & Bayrampaşa & Orta & Bekâr & X \\
\hline 14 & K14,K,30 & Muhasebeci & Lisans & Ümraniye & Orta & Evli & 1 \\
\hline 15 & K15,K,30 & Muhasebeci & YL & Ümraniye & Orta & Bekâr & X \\
\hline 16 & K16,E,42 & Akademisyen & Doktora & Beylikdüzü & Orta & Evli & 1 \\
\hline
\end{tabular}

\section{Veri Toplama Aracı}

Araştırmada veri toplama araçlarını, saha gözlemleri ve gözlem notları, araştırma konusuna dair dokümanların incelenmesi, gerçekleştirilen mülakat soruları oluşturmuştur. Bu araçlara ek olarak özel müzelerin web siteleri, sosyal medya hesapları, görsel ve işitsel reklamlar ve tanıtım broşürleri veri toplama araçlarını oluşturur. Mülakat formu, yarı yapılandırılmıs formu olarak tasarlanarak uygulanmıştır.

\section{İşlem}

Nitel araştırma yönteminin kullanıldığ̀ bu araştırmada 16 katılımcı ile derinlemesine görüşme yapılmıştır. Yarı yapılandırılmıs mülakat formu kullanılmıştır. Katılımcıların izni ile görüşme ses kaydına alınmıştır. Mülakat süresi 15- 75 dakika aralığında olup mülakatların ortalama süresi 37 dakikadır. Mülakat süresi katılımcıların müzeyle olan aidiyetleri nispetinde artış göstermiştir. Deneyimi yüksek olan katılımcıların müzelere ve müzelerin kent ile olan ilişkisine dair açıklamaları bu anlamda daha geniş ölçüdedir.

Görüşmeler neticesinde elde edilen ses kayıtları deşifre edilmiştir Mülakatlar neticesinde 592 dakikalık ses kaydı deşifre edilmiştir. 211 sayfalık “(Times
New Roman, 12 punto, 1.5 satır aralığı) deşifre metni elde edilmiştir.

Çalışmada betimleyici analiz yöntemi kullanılmıştır. Verilerin analizi için ilk aşama olarak mülakat sorularında belirlenen temalar ışı̆̆ında kategoriler belirlenmiştir. Ana kategorilere yardımc1 olacak şekilde alt kategoriler oluşturulmuştur. Daha sonra deşifre metinleri tekrar gözden geçirilmiş ve bu yaklaşımla ana kategoriler yeniden düzenlenmiş benzer alt başlıklar bir araya getirilmiştir. Ses kaydı çözümlemelerinin yeniden okunmasında dikkat çeken ifadeler ilgili başlıklara yazılmıştır. Bu çerçevede elde edilen veriler, araştırmada kullanılan kavram ve teorik yapıyla bir arada değerlendirilerek yorumlanmaya çalışılmıştır.

\section{Bulgular}

Araştırmada 16 kişi ile derinlemesine görüşme yapılmıştır. Bu görüşmeler neticesinde katılımcıların özel müze ziyaretleri, alg1 ve deneyimleri değerlendirilmiştir. Katılımcıların kent ve müze ilişkisine dair fikirleri merak edilmiş bu minvalde sorular yöneltilmiştir. Özel müzelerin, kentin markalaşmasındaki rolü katılımcılar tarafindan değerlendirilmiştir. Özel müzelerin konumları, yer seçimleri ve lokasyonları bu çerçevede ele alınmıştır.

Müzelerin kent ile olan ilişkisine ilişkin katılımcının yanıtı şu şekildedir: 
"Yani müzenin bence müzenin bir kente kattığı en büyük şey imaj. Ben hani bir şehrin imajını yükselten bir değer olarak görüyorum müzeyi. Özellikle turistik değer açısından yani bu denli geçmişi olan bir şehir için özellikle müze kaçınılmaz bir şey yani. Hava gibi su gibi bir şey yani İstanbul üzerinde konuşuyorum. Öte yandan da maddi katkıları da ortada. Yabancı turistler çok fazla. Bu anlamda çok önemli bir şey müze evet.” (K12,E,24)

Özel müzelerin kent için görünür olan yüz olduğu söylenebilir. Bir nevi kentin ekran yüzünü temsil eder. Kente ziyaretçi çekme noktasında önemli bir unsur olarak görev yapar. Katılımcının işaret ettiği husus da bu yöndedir. İstanbul özelinde ise müzeler yerinin kaçınılmaz olduğuna işaret edilmiştir. Zira kentin tarihsel geçmişi ve birikimi kendisini bizatihi müze haline getirmiştir.

"Çünkü kendine bir imaj çalışması yapıyor kişide doğal olarak. Şehir nasıl imaj çalışması yapıyorsa kişilerde imaj çalışması yapıyor ve müze geziyorum, tiyatroya gittim, kültürel aktivitelere katılımlar insanların elitist imajlarını besleyen şeyler hani. O yüzden müze dediğim şey insanın elitist imajına katkı sağlıyor- sa bu doğal olarak bu imajı sağladığı için kentin insanına kente de bir elitist imaj sağlıyor." (K13,K,25)

Müzelerin yer seçimi ve bu seçimin bir sonucu olarak bulunduğu mekân ile ilişkisi katılımcı tarafindan değerlendirilmiştir. Müzelerin bulunduğu semti ekonomik olarak canlandırdığı, hareketlendirdiğgi dile getirilmiştir. $\mathrm{Bu}$ anlamda kültürel mekânların, kentin ekonomik olarak kalkınmasındaki rolüne dikkat çekilmiştir.

"Müze de mekânı besliyor tabi. Müzeye gittiğiniz de etrafindaki esnafa da katkınız oluyor, hali ile bölgenin kalkınmasına katkı sağlanıyor. Bunu bir döngü olarak düşünebiliriz. Dediğim gibi Taksim'in potansiyelinden dolayı müzenin konumlandırması için seçiliyor sonrasinda da müzeler konuma fayda sağliyor ve bir nevi kazan kazan durumu doğuyor. Veya kentin kalkınması istenilen yere de müze yapılabilir ki böylece bölgeye ilgi artsın. Eskiden Osmanlı şehrin hangi yöne doğru büyümesini istiyorsa oraya cami yaparmış ve böylelikle mekân talebini yönlendirebilirmiș. Aynı teknik müze konumlandırmasında da uygulanabilir. Bu yönde en çekici örnek Tate Modern olabilir'(K11,K,30).

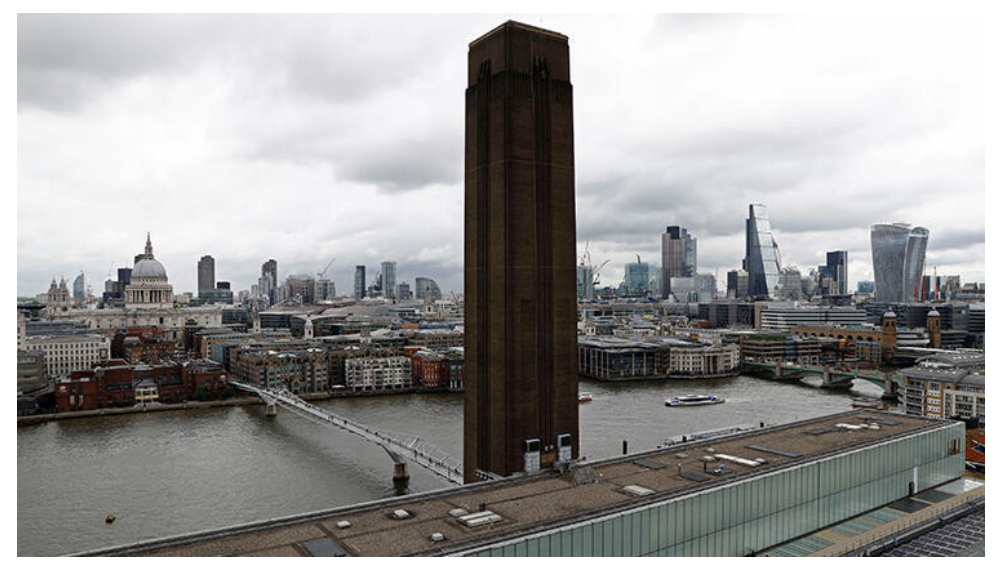

Görsel 4: Tate Modern Müzesi , Kaynak: https://www.hurriyet.com.tr/dunya/sanat-muzesi-tate-modernde-alti-yasinda-bir-cocuk-10-kattan-atildi-41293547 Erişim tarihi: 29.11.2020 
Tate Modern Müzesi'nin kent merkezine yakın olmadığını dile getiren katılımc1, Tate Modern'in yer aldığı bölgeye sadece müze olduğu için gidildiğini farklı bir sebebin bulunmadığını ifade etmiştir. Müzenin bulunduğu bölgeyi canlandırdığını, müze sayesinde bölgenin turist aldığını ve çevresinin de ekonomik anlamda kalkındığını belirtmiştir.

“Aslinda orada bak zaten üniversite yurdu var. Evler falan var ama doğru, Tate Modern olmasa insanlar o tarafa gitmeyecekler. Gerçi karşısında bilmem ne church bir kilisesi var. Ama zaten Tate'i öyle bir yapmışlar ki tam o kilisenin karşısında, Millennium Bridge var, yaya köprüsüi. Sanki böyle iki katedral karşılıklıymış gibi. Tate Modern'den karşıya doğru yürümek çok güzel hissettiriyor kendini sana. Ve ben o yolu da bu yazın ben bayağı bir yürüdüm. Aslında doğru bak. O churchün orayı o katedralin orayı canlandırmış Tate Modern. Oradan yürüyorsun, yoksa o tarafa geçmez başkası ya. Orada başka müzelik bir olay yok çünkü evler falan var orada çünküi... Ama keyifli bir yol. Oradan yürümek insanı mutlı ediyor" (K7,K,30).

Kentin önemli simgeleri olarak değerlendirilen müzeler, aynı zamanda kenti markalaştıran mekânlar olarak ifade edilmiştir. Kentin tanıtılmak istenen mekânlarında yer alan müzeler bir anlamda kendileri için tercih yaparken aynı zamanda kentin simge haline gelen semtlerini ön plana çıkartmaktadir.

"Müze denilince aklıma ne geliyor şehrin simgelerinden biri olarak geliyor. Kenti marka haline getiren noktalarda öyle söyleyeyim. İstanbul'u simge haline getirmiş eski İstanbul'da Suriçi taraflarında olabilir hani anladın mı? Böyle yer- ler yoksa gelip Bayrampaşa'da tabii ki de bir müze açmayacaklardır.” (K13,K,25)

Katılımcıya “O zaman sizin dediğiniz kenti markalaştırmak adına müze bir işlev görüyor böyle mi diyebiliriz?” sorusu sorulduğunda; "Bu bir işlevi evet markalaşırken ama müze kendini de markalaştırıyorken şehrin kendi markalarını da kullanıyor. Ben böyle düşünüyorum ben ikisini birbirinden ayıramam o noktada.” (K13,K,25) cevabını vermiştir.

Kentin merkezi konumunda bulunan özel müzeler, müzenin sürdürülebilirliğini sağlamak adına bu lokasyonları tercih ederken bu durum kent içinde önemlidir. Kentin belli semtlerinde artış gösteren sanat mekânları, kentin o bölgelerinin de tanınırlığının artmasına bir yönüyle de küresel ölçekte markalaşmasına yol açmaktadır. Bu açıdan çift yönlü ilişki söz konusudur.

Kent imajına katkı sağlama noktasında müzeler önemli bir yere sahiptir (Karabıyık Yerden, 2017). Katılımcıların ifadeleri dikkate alındığında bu söylem anlaşılır olacaktır. Kente gelen ziyaretçilerin kenti tanımak adına müzelere başvurduğuna ve bu mekânların turist çektiğine işaret etmiştir.

“İstanbul'a tabi katkısı var özellikle şehir dışından gelenler için İstanbul'da yapılacak aktiviteler açısından bunlar öne çıkan şeyler. İşte Ayasofya’ya gitmeliyim mutlaka gibi. Turist çekiyor müzeler. İngiltere’ye gidenler oradaki müzeleri görmek istiyor tabi ki. Dünya çapında müzeler bunlar. Her ülkeden ziyaretçisi oluyor." (K9,K,30)

Kentin markalaşmasında kültürel unsurların önemi aşikârdır. Nitekim kentin tarihsel geçmişi ve kültürel ürünleri o kenti diğerlerinden ayırt edici kılar. Bu 
çerçevede müzeler Mercin'in ifadesi ile "cazibe mekânlarıdır". Çünkü burada toplumların zaman içerisinde edindikleri bilgiler, yaşantılar gelen misafirlere sunulmaktadır. O kenti tanımak isteyen ziyaretçiler bu anlamda müzeleri merak etmekte ve ziyaret etmektedir (Mercin, 2015, s. 154). Kent adına bir çekim merkezi olan müzeler, o kentin tanıtımında ve markalaşmasında bu yönüyle değerlidir.

"Ya bence kenti markalaştırıyorlar yani kent markalaşıyorken bunlara da önem verilmesi gerekiyor işte sadece mimari yapıyla nasıl diyeyim işte iletişimin mekânı olmakla ondan sonra ticaretin merkezi olmakla şehir markalaşmıyor hani onu markalaştıran şeylerden biri de orada gerçekleştirilen sosyal aktiviteler, kültürel çalışmalar da oluyor." $(\mathrm{K} 13, \mathrm{~K}, 25)$

Kentin markalaşması hususunda uluslararası etkinliklerin önemine değinilmişti. İstanbul Bienali, kentin küresel ölçekte tanınır hale gelmesinde rol oynar. Bienal etkinliğinin yer aldığı mekanlar incelendiğinde özel müzelerin ve sanat kurumlarının yer aldığı Beyoğlu'nun bienal içinde öncelikli merkezi olduğu söylenebilir. Böylelikle küresel ölçekte tanitım kentin markalaşan ve simge merkezleri etrafında şekillenecektir.

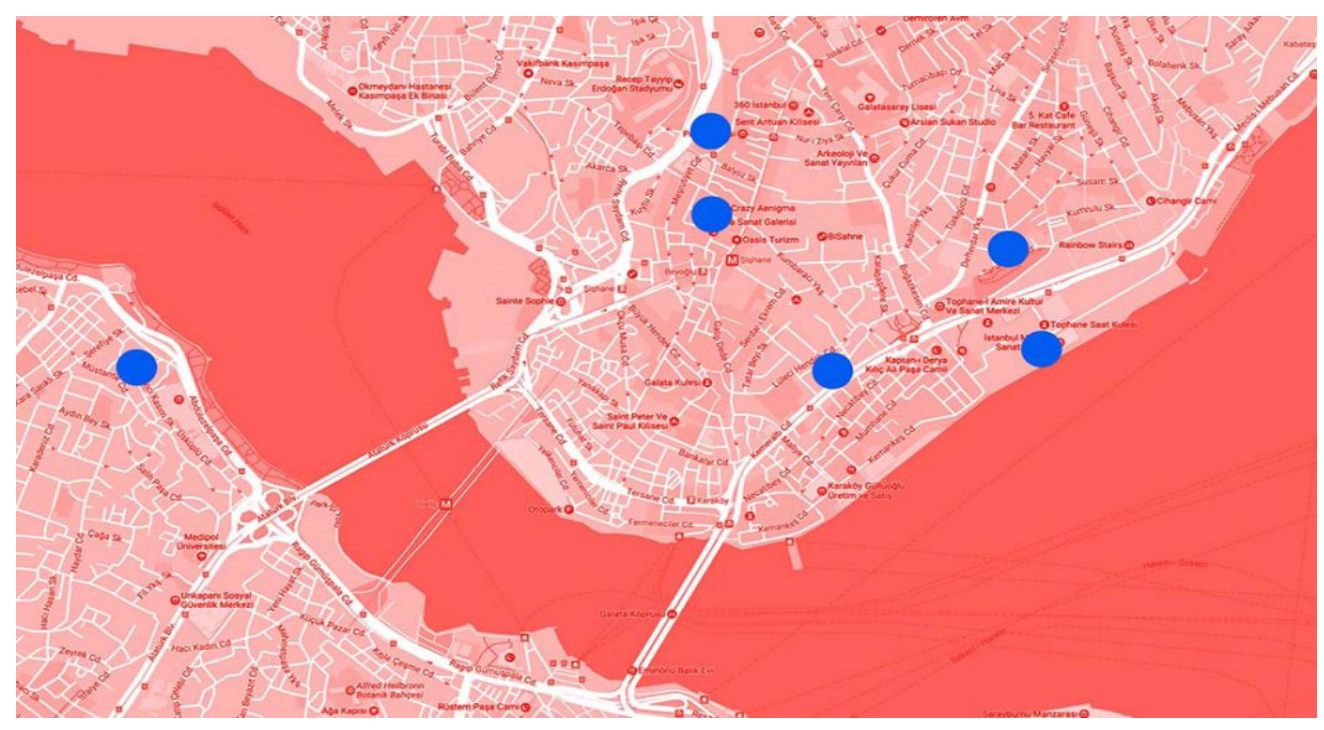

Görsel 5: Bienal etkinliğinin kente dağ1lışı, Kaynak: https://bi-ozet.com/2017/08/15/15-istanbul-bienali-alti-komsu-mekanda-aciliyor/Erişimtarihi: 23.06.2020

15. İstanbul Bienali ‘İyi Bir Komşu’ teması ile kentte birbirine yürüme mesafesinde bulunan mekânlarda konumlanmıştır. Bienal birbirine yakın olan altı komşu mekânda sergilenmiştir. Galata Özel Rum İlköğretim Okulu, İstanbul Modern, Cihangir'deki ARK Kültür, Pera
Müzesi, Küçük Mustafa Paşa Hamamı ve Asmalımescit'te yer alan Yoğunluk Sanatçı Atölyesi sergi alanlarıdır (Bi-özet, 2017). Söz edildiği gibi bienal etkinliğine ev sahipliği yapan mekanlar, kentin simgesi haline gelen semtleri olup kenti markalaştıran mekanlardır. 


\section{Tartıșma}

Küresel kent yarışında kentler yer edinebilmek adına çeşitli çalışmalar yürütmekte olup adeta bir imaj çalışması yapmaktadır. Bu imaj çalışması tasarlanırken kentlerin kendine has özellikleri değerlendirilir. İstanbul örneğinde yürütülen bu araştırmada, kentin tarihi geçmişi ve kültürel birikimine vurgu yapılarak kültürel unsurlar ile söz konusu imaj çalışmasının ele alındığını söylemek mümkündür. Bu çerçevede kentin markalaşmasında kültür ürünlerinin yeri, bu bağlamda müzelerin kentin 'cazibe merkezleri' olarak değerlendirilerek markalaşmada önemli bir unsur olduğu ifade edilebilir.

Kent simgesi olan müzeler, o kente gelenler için bir referans noktası özelliği taşımaktadır. Küreselleşme ile kentlerin adeta yarış içerisine girmesi ve her birinin kendisini özel kılacak unsurları ön plana çıkarması ile tarihsel miras ve kültür ürünlerinin yer artmıştır. Açık hava müzesi olarak değerlendirilen İstanbul gibi bir kent için müzeler bu çerçevede değerlendirildiğinde önem taşımaktadır.

Kentin markalaşma yolunda kent imajına katkı sağlayan kentsel yaşamın maddi olmayan sosyal, kültürel ve tarihi yönleri kullanılmaktadır. Bu minvalde Köksal ve Sarı, şehri "kentsel ürün" şeklinde ele alarak kentin kendine özgü özelliklerine, tarihsel ve kültürel değerlerin önemine vurgu yapmışlardır (Köksal \& Sarı, 2014, s. 280-281). İstanbul'un tarihi kimliği göz önüne alındığında özel müzelerin seçmiş oldukları semtler bu minvalde değerlendirilebilir. Beyoğlu hinterlandında yoğunlaşan sanat galerileri ve müzeler, kentin simge mekânlarıdır. Müzeler hem kenti marka haline getirmekte hem de kentin markalaşan semtlerinde konumlandıkları için kendilerini markalaştırmaktadırlar. Bu çift yönlü bir ilişkidir. Kentin cazibe merkezi olarak değerlendirilmesinde kültür önemli bir araç olup müzeler gibi kültürel mekânlara olan ilgi artmaktadır.

İstanbul'daki özel müzelerin kurulduğu semtler müze kullanıcılarına müze dişında da vakitlerini değerlendirecek ya da kimi ihtiyaçlarını karşlayabilecekleri olanaklar sunmaktadır. Örneğin Taksim bölgesindeki bir müzeye giden kullanıcı için bölge müze deneyiminden öte imkânlar sunmaktadır. Müze ziyaretçisi yalnızca müze deneyimini gerçekleştirmekle kalmaz aynı zamanda kentin farklı sosyal ve kültürel imkânlarını da değerlendirir.

Müzeler, katılımcilar tarafindan turistik mekân olarak değerlendirilmiştir. $\mathrm{Bu}$ anlayış özel müzeler için yüceltilmiş ve kente turist çekme noktasında önemli bulunmuştur. Katılımcilar özel müzeleri kentin öne çıkan farklı, "gösterişli" yüzü olarak değerlendirmiştir. Kent ile müze arasındaki ilişki noktasında bu nokta önemlidir. Zira burada müzelerin yer seçiminde de turistik mekânları seçiyor oluşları dikkat çekmektedir. Nitekim özel müzeler için seçilen mekân yerli ya da yabanci turistlere, kent sakinlerine hitap eden adeta kentin gösterişli bir vitrini olabilecek yerlere kurulmuştur.

Müzelerin kentin vitrini bir anlamda tanıtıcı yüzü olması kentlerin uluslararası düzeyde kendilerini var etme çabalarıyla da örtüşmektedir. Burada vurgulanan husus küreselleşme ile kentlerin yeni konumlarıdır. Kentlerin küreselleşen kentler ağ i içinde kendilerine yer bulmalarının bir yönü de kültür, sanat ürünlerinin pazarlanmasıdır. İstanbul'un 2010 kültür başkenti seçilmesi bu yaklaşımın bir uzantısıdır. Kentin tanıtımı ve pazarlanmasında özel müzeler adeta renkli bir ekran görevi görmektedir. 


\section{Kaynakça}

Akaş, C. (2006). Haliç̧'in Kıyısında Endüstriyel Arkeoloji. İstanbul: Rahmi M. Koç Müzesi.

Aktuğlu, Y. K., \& Balık, D. (2009, Nisan 29). 20. Yüzyılın Müzesi Bilbao Guggenheim, Gehry ve Biz. v3 arkitera: https://v3.arkitera.com/news.php?action=displayNewsItem \&ID=40845 adresinden alınd 1

Bi-özet. (2017, Ağustos 15). 15. İstanbul Bienali Altı Komşu Mekanda Açıldı! Haziran 23, 2020 tarihinde Bi-özet: https://bi-ozet.com/2017/08/15/15-istanbul-bienali-alti-komsu-mekanda-aciliyor/ adresinden alındı

Cançat, A. (2016). 2010 Avrupa Kültür Başkenti İstanbul Kültür Ve Sanat Projelerinin Kurumsal Disiplinleri;İstanbul Kültür Ve Sanat Vakfi,Kültür A.Ş. Örneği. ART-SANAT, 229-241.

Çalıkoğlu, L. (2009). Koleksiyon, Koleksiyonerlik ve Müzecilik. İstanbul: Yapı Kredi Yayınları.

Hein, C. (2010). Avrupa Kültür Başkenti Programı ve İstanbul 2010. D. Göktürk, L. Soysal, \& İ. Türeli içinde, İstanbul Nereye? Küresel Kent, Kültür, Avrupa (s. 329-359). İstanbul: Metis Yayınları.

Henden Şolt, B. (2018). Zonguldak Ereğli Kent Markalaşması Ve Kentsel İmaj Algısı. Yönetim Ve Ekonomi Araștırmaları Dergisi, 128-144.

İlhan, Z. (2019). Bir Üretim Biçimi Olarak Sanat, Toplumsal Beğeni-Sermaye İlișkisi: İstanbul Örneği. İstanbul: Maltepe Üniversitesi Sosyal Bilimler Enstitüsü.

İstanbul İl Kültür ve Turizm Müdürlüğü. (2018). İstanbul Kültür Çalıștayı/ Çalıștay Kitabı. İstanbul: Bilnet Matbaacılık ve Yayıncılık A.Ş.

Karabıyık Yerden, N. (2017). Kültür Pazarlaması. İstanbul: Türkmen Kitabevi.

Karabıyık Yerden, N. (2017). Kültür Pazarlaması . İstanbul: Türkmen Kitabevi .

Koçyiğit, M., \& Aktan, E. (2020). Kent Markalaşması Bağlamında Tematik Parkların Kent İmajı Üzerindeki Rolü: Konya Kelebekler Vadisi Ziyaretçileri Üzerine Bir Araştırma. Gümüşhane Üniversitesi İletişim Fakültesi Elektronik Dergisi, 8(1), 1-20.

Köksal , Y., \& Sarı, S. (2014). Burdur Kent İmajının Yerel Halk İle Üniversite Öğrencileri Arasındaki Karşılaştırmalı Bir İncelemesi . Dumlupınar Üniversitesi Sosyal Bilimler Dergisi, 279-288.

Mercin, L. (2015). Müzeler Ve Toplum. T.C. Kültür Ve Turizm Bakanlığı Atatürk Kültür, Dil Ve Tarih
Yüksek Kurumu: https://www.ayk.gov.tr/wp-content/uploads/2015/01/Yrd.-Do\%c3\%a 7.-Dr.-Levent-MERC\%c4\%b0N-M\%c3\%9cZELER-VE-TOPLUM. pdf adresinden alınd 1

Mimarizm. (2009, Aralık 4). Avrupa Kültür Başkenti Nedir? Ocak 4, 2020 tarihinde Mimarizm : http://www.mimarizm.com/makale/avrupa-kultur-baskenti-nedir_114257 adresinden alındı

Öktem, P., \& Görgülü, T. (2011, Ocak-Şubat). 1985’ten bugüne Avrupa Kültür Başkentleri Ve İstanbul. Ekim 21, 2019 tarihinde Mimarlık Dergisi: http:/| www.mimarlikdergisi.com/index.cfm?sayfa $=$ mimarlik\&DergiSayi $=371 \&$ RecID $=2567$ adresinden alındı

Özpınar, C. (2011). Birey,Kent ve Kamusal Mekan Bağlamında İstanbul Bienali. Kült-Kültürel İncelemeler Dergisi, 263-283.

Pirnar, İ., \& Kurtural, S. (2017). Kent Markalaşmasında Müzelerin Rolü Ve İzmir Mega Müze Projesi . Uluslararası İktisadi ve İdari İncelemeler Dergisi, 491 - 502.

Şeni, N. (2011). İstanbulida Özel Kültür Politikası ve Kentsel Alan . İstanbul: İstanbul Bilgi Üniversitesi Yayınları.

Tonguç, S. E. (2017, Temmuz 10). Bir Șehrin Kaderini Değiștiren İlginç Müze. Haziran 20, 2020 tarihinde Hürriyet Seyahat: https://www.hurriyet. com.tr/seyahat/yazarlar/saffet-emre-tonguc/bir-sehrin-kaderini-degistiren-ilginc-muze-40512470 adresinden alındı

World Tourism Group. (tarih yok). Guggenheim Bilbao: Sanat Tarihi Yapmak. Kasım 29, 2020 tarihinde World Tourism Group: https:/|tur.worldtourismgroup. com/guggenheim-bilbao-65655 adresinden alındı

Yalım, F. (2017). Yavaş Şehir(Cıttaslow) Hareketi Ekseninde Kent Markalaşması Ve Kent İletişimi: Kırklareli "Vize" Yavaş Şehir Örneği . Trakya Üniversitesi İktisadi ve İdari Bilimler Fakültesi Dergisi, 1-28.

Yardımcı, S. (2014). Kentsel Değişim ve Festivalizm: Küreselleșen İstanbul'da Bienal. İstanbul: İletişim Yayınları.

Yavuz, F. (2009, Aralık 10). "Dünyanın En İtham Verici Kenti"2010'a Hazır! Ocak 4, 2020 tarihinde Mimarizm: http://www.mimarizm.com/haberler/dunyanin-en-ilham-verici-kenti-2010-a-hazir_116546?sourceId $=114243$ adresinden alınd 1

Zeren, H. E. (2012). Kent Markalaşması Sürecinde İç Girişimcilik Faktörü. Kahramanmaraş Sütçü İmam Üniversitesi İktisadi ve İdari Bilimler Fakültesi Dergisi, 95-104. 